\title{
Sources and Genetics of Resistance to Soybean Rust Phakopsora pachyrhizi (H. Sydow \& Sydow) in Nigeria
}

\author{
G. A. Iwo ${ }^{1}$, M. A. $\operatorname{Ittah}^{1} \&$ E. O. Osai ${ }^{1}$ \\ ${ }^{1}$ Department of Crop Science, University of Calabar, Calabar, Cross River State, Nigeria \\ Correspondence: G. A. Iwo, Department of Crop Science, University of Calabar, P. M. B 1115, Calabar, Cross \\ River State, Nigeria. E-mail: akpaniwo@yahoo.com
}

Received: August 26, 2011 Accepted: September 26, 2011 Online Published: August 24, 2012

doi:10.5539/jas.v4n10p1 URL: http://dx.doi.org/10.5539/jas.v4n10p1

\begin{abstract}
In searching for resistance genes to soybean rust (Phakopsora pachyrhizi (H. Sydow \& Sydow), twenty eight soybean genotypes obtained from the International Institute for Tropical Agriculture (IITA) Ibadan were screened on rust infested field for resistance to rust. These genotypes were planted at the National Cereals Research Institute (NCRI), Yandev station in Benue State, Nigeria during 2007 and 2008 cropping seasons. Soybean rust is known to be endemic to the Yandev station. Field observations revealed significant variation among the soybean genotypes to rust. Seven soybean genotypes were identified to be resistant to rust which were TGx1987-62F, TGx1935-3F, TGx1951-3F, TGx1936-2F, TGx1987-10F, TGx1972-1F and TGx1949-8F. Genetic analysis of the parental materials after hybridization for the mode of inheritance indicated that rust resistance in soybean was monogenically controlled by dominant genes. The relationship among the resistance genes was established through allelic testing which indicated that genes in TGx1972-1F and TGx1987-10F are allelic and independent of the dominant resistance genes of TGx1951-3F, TGx1936-2F, TGx1987-62F and TGx1935- 3F which are also allelic. The results revealed that dominant alleles at three loci conditioned resistance to soybean rust races found in Nigeria and the tentative symbols formulated for the three loci controlling resistance to rust in soybean were Rsbr1, Rsbr2 and Rsbr3 (Resistance to soybean rust )
\end{abstract}

Keywords: disease, inheritance, resistance, rust, soybean

\section{Introduction}

Soybean (Glycine $\max (\mathrm{L})$ Merrill) is the most important oilseed and grain legume in the world. The seed has the largest usable protein content among all cultivated legumes especially after it has been heated to inactivate the anti-metabolites. Soybean is also rich in carbohydrate, calcium, iron and vitamins. The crop contains no cholesterol; for this reasons, soybean is mainly used for food, medicine and animal feed production. Soybean oil is currently considered for the production of bio-fuel in many countries, as a safe and environment friendly alternative to petroleum (Bassey, 2010; Nielsen, 2010). In spite of these qualities, the crop has not been widely cultivated especially in Africa due to some biotic factors.

One of the most important biotic factors that constrain soybean production is the soybean rust caused by the fungus Phakopsora pachyrhizi (H.Sydow \& Sydow) (Miles et al., 2007). This is one of the most economically important foliar diseases affecting soybean world wide (Hartman et al., 2005). Soybean rust was first reported in Japan 1903 and had been known in Asia for more than 100 years (Hartman et al., 2005). It is a new pathogen in Africa (Levy, 2005; Shokalu et al., 2000). In Africa, soybean rust was first observed around Zimbabwe and Uganda in 1997 (Levy, 2005). It has spread to South Africa (du Preez et al., 2005) and the West Africa region. The disease was first observed in Nigeria in 1999 (Shokalu et al., 2000; Akinsanmi et al., 2001) and now endemic to major soybean growing areas in the country. Soybean rust is the most destructive foliar disease of soybean, and yield losses of over $50 \%$ are common when environmental conditions are conducive for the disease development (Glen et al, 2005). Heavily infected plants defoliate and mature more rapidly than plants not infected with rust. Evidence of the devastation of soybean by the rust have been reported worldwide; in Australia, Asia, Europe, South America, USA and South Africa (Pivonia \& Yang, 2004; du Preez et al., 2005; Ivancovich, 2005; Levy, 2005; Peterson \& Kosta, 2005, Pivonia et al., 2005; Yorinori et al., 2005). Yorinori et al. (2005) estimated that 3.4 million tonnes of grains worth US\$759 million was lost to soybean rust disease in the USA alone in 2003. The control of this devastating disease has been difficult because of availability of many physiological races of the pathogen. 
Previous studies of soybean resistance to soybean rust by Bromfield and Hartwig (1980), Bromfield et al. (1980), Mclean and Byth (1980), Hartwig and Bromfield (1983) and Hartwig (1986) revealed that four single dominant genes confer specific resistance to infection caused by some races of rust. The absence of high levels of host resistance to the pathogen has necessitated the continued search and identification of sources of resistance. There is no control method other than genetic resistance that would resist the infestation of the rust pathogens. The objectives of this study were to identify sources of resistance genes to the physiological races of soybean rust prevalent in Nigeria, determine the mode of inheritance and assess the possible allelic relationship between the resistance genes.

\section{Materials and Methods}

The experiment was conducted at the National Cereals Research Institute (NCRI), Yandev station in Benue State, Nigeria. Benue State is a major soybean growing area in Nigeria and Yandev is located at latitude $7^{\circ} 49^{\prime \prime} \mathrm{N}$ and longitude $8^{0} 32^{\prime}$ E with annual temperature of $33^{\circ} \mathrm{C}$ and rainfall of $2100 \mathrm{~mm}$.

Twenty-eight soybean genotypes were obtained from the Grain Legume Improvement Program (GLIP) of the International Institute for Tropical Agriculture (IITA), Ibadan, Nigeria. These were screened in the field for their reaction to rust disease in the 2007 and 2008 cropping seasons. The soybean genotypes used for field experimentation included TGx1932-IF, TGx1935-3F, TGx1945-IF, TGx1951-3F, TGx1951-4F, TGx1954-IF, TGx1971-1F, TGx1972-1F, TGx1977-2F, TGx1977-4F, TGx1935-5F, TGx1936-2F, TGx1937-IF, TGx1939-2F, TGx1949-10F, TGx1949-7F, TGx1949-8F, TGx1950-8F, TGx1955-4F, TGx1956-1F, TGx1963-3F, TGx1440-1E, TGx1448-2F, TGx1485-1D, TGx1987-62F, TGx1844-18F, TGx923-2F, TGx1987-10F. The field used for the screening was naturally infested and soybean rust disease is known to be endemic to Yandev

The soybean genotypes were grown in a randomized complete block design with three replications. Each genotype was represented in 2-rows plots of 5 meters length with $50 \mathrm{~cm}$ spacing between rows and $15 \mathrm{~cm}$ between plants. Weeds were manually hoed three weeks after planting and thereafter hand pulling followed continuously at two weeks interval.

Mean scale measurement of 1-5 for the disease severity, suggested by Shokalu et al. (2000) was adopted. The scale measurement was expressed as follows

$1=$ No infection (no visible lesion on the leaves and the shoot)

$2=$ Slight infection (1-20\% of the shoot showed symptoms of the disease with few scattered lesions)

$3=$ Moderate infection ( disease symptoms appeared on $21-40 \%$ of the shoot)

$4=$ Severe infection ( disease symptoms appeared on $41-70 \%$ of the shoot)

$5=$ Very severe infection (Prolific lesion development over most of the leaves on the shoot. Over $70 \%$ of the shoots are infected).

$$
\text { Incidence of infection }(\%)=\frac{\text { No of infected plant }}{\text { No of plants in the plot }} \times \frac{100}{1}
$$

The plants were rated as resistant or susceptible on the basis of the lesion type present. Severity scoring of rust infection on soybean was carried out 3 weeks after germination ( $3 \mathrm{WAG}$ ), $5 \mathrm{WAG}, 7 \mathrm{WAG}$, and $9 \mathrm{WAG}$ respectively. The number of soybean plants infected with rust were counted and recorded alongside the total grain yield per plot at harvest.

Based on the reactions of the soybean genotypes to rust during screening on the field, the following pairs of crosses between resistant and susceptible parents were used for determination of mode of inheritance of the resistance gene(s) to soybean rust. The seven resistant parents identified after evaluation in the naturally infected field included: TGx1987-62F, TGx1951-3F, TGx1949-8F, TGx1987-10F, TGx 1935-3F, TGx1972-1F, TGx1936-2F and a susceptible line TGx923-2F for the crossing combinations. The derived seeds of the $\mathrm{F}_{1}$ plants of each cross were grown in plastic buckets of 5 liters volume in the screen house. The $F_{1}$ progenies were backcrossed to TGx923-2F (a susceptible parent) to produce first backcross progenies $(\mathrm{BC} 1)$ and some of the $\mathrm{F}_{1}$ plants from each of the crosses were allowed to self-fertilize to produce the $F_{2}$ population. For the determination of the allelic relationship, crosses were carried out between the seven resistant lines.

The $\mathrm{F}_{1}, \mathrm{~F}_{2}$, and $\mathrm{BC} 1$ of the various crosses were taken to rust infected field where they were planted in a randomized complete block design with three replicates. The $\mathrm{F}_{1}$ and $\mathrm{BC} 1$ generations were represented in 2- row plots each while $\mathrm{F}_{2}$ were planted in 3- row plots of $5 \mathrm{~m}$ length with $50 \mathrm{~cm}$ spacing between rows and $15 \mathrm{~cm}$ between plants. Progenies of these $\mathrm{F}_{1}, \mathrm{~F}_{2}$ and $\mathrm{BC} 1$ generations were scored for their reactions to soybean rust and were used for 
determining the mode inheritance and the allelic relationships of the resistance genes. Chi-square analyses were conducted for the population to test for goodness of fit.

\section{Results and Discussion}

\subsection{Field Experiment}

Field observations showed that leaf and shoot infection of soybean by rust ( $P$. pachyrhizi) varied according to interval after germination. At three weeks after germination ( $3 \mathrm{WAG}$ ), symptom of rust was initially observed only on three soybean genotypes as small lesions on the lower surface of the first leaf which appeared necrotic as the plants grow. Among the infected soybean genotypes were TGx 1939-2F, TGx1949-7F and TGx1950-8F. At 5-7 WAG, the level infection spread progressively to about $70 \%$ of the plant population on the field. At this stage, lesions with larger area of necrosis that are reddish brown were observed on most of the soybean genotypes with severity score ranging from 2.0- 5.0. As the plants mature and set pods at 9 WAG, infection spread to the upper surface of the leaves. At this podding stage, seven genotypes were identified in the field to be resistant to soybean rust with mean disease severity score of $1.0-2.3$. The resistant genotypes included TGx1987-62F, TGx1935-3F, TGx 1951- 3F, TGx1936-2F, TGx1987-10F, TGx1972-1F and TGx1949-8F.

Generally there was significant variation among the soybean genotypes in their reactions to rust disease. The grain yields at harvest were high among the resistant genotypes when compared with the susceptible genotypes. Higher grain yields were obtained from TGx 1972-1F, TGx1987-10F, TGx1987-62F, TGx1935-3F and TGx1936-2F within the range of $300-364 \mathrm{gm} / \mathrm{plot}$ (Table 1).

Table 1. Mean values for field Performance and Rust Disease Severity Score of Soybean Genotypes in 2007/2008

\begin{tabular}{|c|c|c|c|c|c|c|}
\hline \multirow[t]{2}{*}{ Entries } & \multirow{2}{*}{$\begin{array}{l}\text { Disease } \\
3 W A G\end{array}$} & \multirow{2}{*}{$\begin{array}{l}\text { Severity } \\
\text { 5WAG }\end{array}$} & \multirow{2}{*}{$\begin{array}{l}\text { Score } \\
\text { 7WAG }\end{array}$} & \multicolumn{2}{|c|}{ Reaction } & \multirow{2}{*}{$\begin{array}{c}\text { Total } \\
\text { grain yield } \\
\text { gm/plot. }\end{array}$} \\
\hline & & & & $9 \mathrm{WAG}$ & to rust & \\
\hline TGX 1440-1E & 1.7 & 2.0 & 3.3 & 4.0 & $\mathrm{~S}$ & 193.2 \\
\hline TGX 1448-2F & 1.0 & 2.7 & 2.3 & 3.0 & $\mathrm{M}$ & 177.6 \\
\hline TGX 1485-1D & 2.3 & 3.5 & 5.0 & 5.0 & HS & 73.15 \\
\hline TGX 1987-62F & 1.0 & 1.0 & 1.0 & 1.6 & HR & 330 \\
\hline TGX 1844-18F & 2.0 & 2.7 & 3.0 & 4.3 & $\mathrm{~S}$ & 144.5 \\
\hline TGX 1932-1F & 2.0 & 2.7 & 3.3 & 4.0 & $\mathrm{~S}$ & 217 \\
\hline TGX 1935-3F & 1.0 & 1.0 & 2.0 & 1.0 & HR & 364 \\
\hline TGX 1935-5F & 1.0 & 2.0 & 2.0 & 3.0 & MR & 246 \\
\hline TGX 1936-2F & 1.0 & 1.0 & 1.7 & 2.3 & $\mathrm{R}$ & 322 \\
\hline TGX 1937-1F & 1.7 & 2.0 & 2.3 & 3.0 & MR & 205 \\
\hline TGX 1939-2F & 2.5 & 3.7 & 4.0 & 5.0 & HS & 101 \\
\hline TGX 1945-1F & 2.0 & 2.7 & 4.3 & 4.0 & $\mathrm{~S}$ & 198. \\
\hline TGX 1949-10F & 2.3 & 3.3 & 4.7 & 4.7 & HS & 110 \\
\hline TGX 1949-7F & 2.7 & 3.5 & 4.0 & 5.0 & HS & 118 \\
\hline TGX 1949-8F & 1.3 & 1.7 & 2.0 & 2.0 & $\mathrm{R}$ & 265 \\
\hline TGX 1950-8F & 2.0 & 3.5 & 5.0 & 5.0 & HS & 195 \\
\hline TGX 1951-3F & 1.0 & 1.0 & 1.0 & 2.0 & $\mathrm{R}$ & 253 \\
\hline TGX 1951-4F & 1.7 & 2.7 & 2.3 & 4.3 & $\mathrm{~S}$ & 153 \\
\hline TGX 1954-1F & 2.0 & 4.0 & 4.0 & 5.0 & HS & 107 \\
\hline TGX 1955-4F & 2.5 & 3.7 & 5.0 & 5.0 & HS & 204 \\
\hline TGX 1956-1F & 2.3 & 3.0 & 4.7 & 5.0 & HS & 181 \\
\hline TGX 1963-3F & 2.1 & 3.5 & 4.0 & 5.0 & HS & 116 \\
\hline TGX 1987-10F & 1.0 & 1.0 & 1.3 & 1.7 & HR & 300 \\
\hline TGX 1971-1F & 2.3 & 3.7 & 4.3 & 5.0 & HS & 159.3 \\
\hline TGX 1972-1F & 1.0 & 1.0 & 1.3 & 1.7 & HR & 359 \\
\hline TGX 1977-2F & 2.5 & 3.7 & 4.0 & 5.0 & HS & 225 \\
\hline TGX 1977-4F & 2.3 & 3.3 & 4.0 & 5.0 & HS & 105 \\
\hline TGX 923-2F & 2.5 & 3.9 & 4.0 & 5.0 & HS & 97.6 \\
\hline Mean & 1.88 & 2.63 & 3.20 & 3.80 & & 197.2 \\
\hline $\pm S E$ & 0.14 & 0.21 & 0.25 & 0.26 & & 16.03 \\
\hline $\mathrm{CV} \%$ & 38.0 & 39.5 & 40.5 & 36.0 & & 41.5 \\
\hline
\end{tabular}

Key: WAG = Week after germination, $\mathrm{S}=$ Susceptible, MS=Moderately Susceptible, HS=highly susceptible, HR=Highly Resistant, MR=Moderately Resistant, $\mathrm{R}=$ Resistant. 


\subsection{Mode of Inheritance of Resistance Gene(s) to Rust (P. pachyrhizi) in Soybean}

The reactions of the $\mathrm{F}_{1}$ population from crosses between the susceptible and seven resistant parents (TGx1987-62F x TGx923-2F, TGx1951-3F x TGx923-2F, TGx1972-1F x TGx923-2F, TGx1949 -8F x TGx923-2F, TGx1935-3F x TGx923-2F, TGx1987-10F x TGx923-2F, TGx1936-2F x TGx923-2F) to rust (P. pachyrhizi) are presented in Table 2.

Table 2. Reaction of Soybean Progeny from Crosses of Susceptible TGX923-2F with Resistant Lines to Soybean Rust and their Backcross

\begin{tabular}{llllllllllll}
\hline Population & \multicolumn{1}{c}{$\mathrm{F}_{1}$ population } & \multicolumn{3}{c}{$\mathrm{F}_{2}$ population } & \multicolumn{5}{c}{ BCI } \\
\hline & Res. & Sus. & Res. & Sus. & $\mathrm{X}^{2}$ & $\mathrm{P}$. & Res. & Sus. & $\mathrm{X}^{2}$ & P. \\
& No. & No. & No & No & $3: 1$ & & No & No. & $1: 1$ \\
\hline TGx 923-2F x TGx 1987-62F & 38 & 0 & 274 & 93 & 0.022 & $0.5-0.75$ & 52 & 47 & 0.73 & $0.20-0.50$ \\
TGx 923-2F x TGx 1951-3F & 30 & 0 & 259 & 88 & 0.024 & $0.5-0.75$ & 33 & 26 & 0.51 & $0.50-0.75$ \\
TGx 923-2F x TGx 1972-1F & 28 & 0 & 263 & 85 & 0.061 & $0.75-0.90$ & 46 & 41 & 0.82 & $0.50-0.50$ \\
TGx 923-2F x TGx 1949-1F & 28 & 0 & 261 & 84 & 0.076 & $0.50-0.75$ & 38 & 29 & 0.50 & $0.20-0.50$ \\
TGx 923-2F x TGx 1935-1F & 26 & 0 & 248 & 85 & 0.049 & $0.75-0.90$ & 30 & 26 & 0.26 & $0.50-0.75$ \\
TGx 923-2F x TGx 1987-1F & 33 & 0 & 249 & 78 & 0.029 & $0.50-0.75$ & 30 & 27 & 0.26 & $0.50-0.75$ \\
TGx 923-2F x TGx 1936-1F & 35 & 0 & 260 & 70 & 0.031 & $0.50-0.75$ & 35 & 31 & 0.53 & $0.20-0.50$ \\
\hline
\end{tabular}

The observation showed no symptom of rust infection on the leaves and shoots of the $F_{1}$ plants. The plants growth was normal, no lesions on the lower or upper surfaces of the leaves.

The $F_{1}$ populations were generally resistant indicating the dominant nature of the resistance genes in these soybean genotypes. On the other hand, there was a genetic segregation among the $F_{2}$ population derived from the crosses. The $\mathrm{F}_{2}$ showed a segregation ratio of 3 resistant: 1 susceptible crop stand indicating that resistance in each case was governed by a single dominant gene. A backcross of the $\mathrm{F}_{1}$ generation to the susceptible parent $\mathrm{BC} 1$ (TGx923-2F $\mathrm{x}$ $F_{1}$ ) in each case segregated into a ratio of 1 resistant: 1 susceptible. This confirms the monogenic nature of the inheritance.

\subsection{Allelic Relationship of the Resistance Genes in Soybean Genotypes}

Studies on the $F_{1}$ and $F_{2}$ progenies of the crosses between resistant soybean genotypes; TGx1987-62F, TGx1951-3F, TGx1949-8F, TGx1987-10F, TGx1935-3F, TGx1972-1F, TGx1936-2F to determine the allelic relationship of the resistance genes showed that all the $F_{1}$ progenies were resistant to rust. The segregation data of the $F_{2}$ population from the crosses between the resistant genotypes fitted into a 15 resistant: 1 susceptible ratio based on the expectation of independent segregation in these populations (Table 3 ). There was no segregation from the crosses between TGx1972-1F x TGx1987-10F, TGx1951-3F x TGx1936-2F, and TGx1987-62F x TGx1935-3F. The absence of susceptible segregation from these three crosses showed that the dominant resistance genes of TGx1972-1F and TGx1987-10F are allelic and independent of the dominant resistance genes of TGx 1951-3F, TGx1936-2F, TGx1987-62F and TGx1935-3F which are also allelic.

The results therefore revealed the existence of more than two loci controlling resistance to soybean rust $(P$. pachyrhizi) and the dominant alleles at three loci conditioned resistance. The gene symbols at the three loci can be tentatively formulated accordingly, Rsbr1, Rsbr2 and Rsbr3 (resistance to soybean rust). This report conforms to the earlier findings of Hartwig and Bromfield (1983)

Host plant resistance has been an acceptable approach to the control of pathogenic infection and the stability of such resistance is very important in crop improvement programmes. The prospect of controlling soybean rust $(P$. pachyrhizi) using resistance varieties will be enhanced by the identified resistance genes. These genes can be incorporated into improved and adaptable soybean cultivars. The mode of inheritance of the resistance genes among the identified soybean genotypes showed that the resistance is controlled by dominant genes and the simple nature of inheritance will ensure easier transfer of the genes. However, resistance due to simple dominant genes breakdown easily whenever these is evolution of races or strains of pathogen organisms. In Nigeria, soybean rust is new and is prevalent to Yandev in North central Nigeria and Ogbomosho in South West Nigeria. The strains of soybean rust are likely to be different from other parts of the world. In this case, breeding for soybean rust 
resistance may be complicated due to existence of races which are sometimes ecotypic. Therefore, there is need for identification of multiple genes for broad-based resistance to rust in soybean growing areas.

Table 3. Response of $\mathrm{F}_{1}$ and $\mathrm{F}_{2}$ Populations from Crosses between Resistant Soybean Genotypes to Rust ( $P$. pachyrhizi)

\begin{tabular}{lcccccc}
\hline & \multicolumn{7}{c}{$\mathrm{F}_{1}$ POPULATION } & \multicolumn{2}{c}{$\mathrm{F}_{2}$ POPULATION } & \\
\hline Crosses & Res. & Sus. & Res. & Sus. & $\mathrm{X}^{2}$ & $\mathrm{P}$ \\
& No. & No. & No. & No. & & \\
\hline TGx 1972-1F x TGx 1951-3F & 29 & 0 & 289 & 19 & 0.013 & $0.050-075$ \\
TGx 1972-1F x TGx 1805-1F & 29 & 0 & 320 & 21 & 0.046 & $0.50-0.75$ \\
TGx 1972-1F x TGx 1987-10F & 31 & 0 & 289 & 0 & & \\
TGx 1972-1F x TGx 1949-8F & 38 & 0 & 342 & 22 & 0.059 & $0.75-0.90$ \\
TGx 1972-1F x TGx1935-3F & 36 & 0 & 310 & 20 & 0.034 & $0.50-0.75$ \\
TGx 1972-1F x TGx1936-2F & 32 & 0 & 328 & 21 & 0.053 & $0.75-0.90$ \\
TGx 1951-3F x TGx1805-1F & 38 & 0 & 276 & 18 & 0.014 & $0.50-0.75$ \\
TGx 1951-3F x TGx1987-10F & 36 & 0 & 305 & 20 & 0.076 & $0.75-0.90$ \\
TGx 1951-3F x TGx1949-8F & 33 & 0 & 321 & 21 & 0.046 & $0.75-0.90$ \\
TGx 1951-3F x TGx1935-3F & 35 & 0 & 340 & 22 & 0.059 & $0.75-0.90$ \\
TGx 1951-3F x TGx1936-2F & 30 & 0 & 211 & 0 & & \\
TGx 1951-3F x TGx1987-10F & 32 & 0 & 290 & 19 & 0.027 & $0.50-0.75$ \\
TGx 1951-3F x TGx1949-8F & 34 & 0 & 321 & 21 & 0.046 & $0.50-0.75$ \\
TGx 1951-3F x TGx1935-3F & 36 & 0 & 300 & 0 & & \\
TGx 1951-3F x TGx1936-2F & 33 & 0 & 315 & 21 & 0.052 & $0.75-0.90$ \\
\hline
\end{tabular}

\section{Acknowlegements}

I wish to acknowledge the assistance rendered to us by the Grain Legume Improvement Program (GLIP) of the International Institute for Tropical Agriculture (IITA) Ibadan, Nigeria in providing the planting materials (Soybean seeds). My appreciation also goes to the National Cereals Research Institute, Badeggi for granting us the permission to conduct the experiment on their field at Yandev station where rust infection is endemic in addition to provision of logistic support.

\section{References}

Akinsanmi, O. A., Ladipo, J. L., \& Oyekan, P. O. (2001). First report of soybean rust in Nigeria. Plant disease, 85, 97. http://dx.doi.org/10.1094/PDIS.2001.85.1.97B

Bassey, M. (2010). Who benefits from the population of fuels for cars? The answer is clear. Farming matters, 12 , 29.

Bromfield, K. R., \& Hartwiz, E. E. (1980). Resistance to soybean rust (Phakopsora pachyrhizi) and mode of inheritance. Crop Science, 20, 254-55.

Bromfield, K. R., Melching, J. S., \& Kingsolver, C. H. (1980) Virulence and aggressiveness of Phakopsora

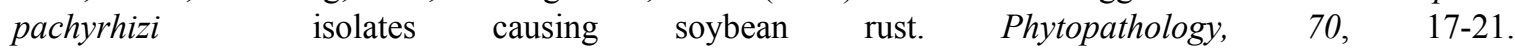
http://dx.doi.org/10.1094/Phyto-70-17

du Preez, E. D., van Rij, N. C., \& Lawrence, K. F. (2005). First report of soybean rust caused by Phakopsora pachyrhizi on dry beans in South Africa. Plant disease, 89, 206. http://dx.doi.org/10.1094/PD-89-0206C

Glen, L. H., Monte, R. M., \& Reid, D. F. (2005). Breeding for resistance to soybean rust. Plant disease, 89 , 664-666. http://dx.doi.org/10.1094/PD-89-0664

Hartman, G. L., Miles, M. R., \& Frederick, R. D. (2005). Breeding for resistance to soybean rust. Plant Disease, 89, 664-666. http://dx.doi.org/10.1094/PD-89-0664

Hartwig, E. E. (1986). Identification of a fourth major gene conferring resistance to soybean rust. Crop Science, 26, 1135-1136. http://dx.doi.org/10.2135/cropsci1986.0011183X002600060010x

Hartwig, E. E., \& Bromfield, K. R. (1983). Relationship among three genes conferring specific resistance to rust in soybean. Crop Science, 23, 237-239. http://dx.doi.org/10.2135/cropsci1983.0011183X002300020012x 
Ivancovich, A. (2005). Soybean rust in Argentina. Plant Disease, 89, 667-668. http://dx.doi.org/10.1094/PD-89-0667

Kochman, J. K. (1977). Soybean rust in Australia. pp. 44-48. In Ford, R. E. and Sinclair, J. B. (eds) Rust of soybean- the problem and research needs. INTSOY series No. 12. Urbana, University of Illinois.

Levy, C. (2005). Epidemiology and chemical control of soybean rust in Southern Africa. Plant Disease, 89, 669-674. http://dx.doi.org/10.1094/PD-89-0669

Mclean, R. L., \& Byth, D. E. (1980). Inheritance of resistance to rust (phakopsora pachyrhizi) in soybean. Austrian Journal of Agricultural Research, 31, 951-956. http://dx.doi.org/10.1071/AR9800951

Miles, M. R., Frederick, R. D., \& Hartman, G. L. (2007). Soybean rust: is the US soybean crop at risk? http://www.apnet.org/online/feature/rust downloaded 20/5/2007.

Nielsen, F. (2010). Can family benefit from bio-fuels? Farming Matters, 12, 28.

Peterson, G. I., \& Kosta, K. L. (2005). Soybean rust: too close for comfort. Plant Disease, 89, 663. http://dx.doi.org/10.1094/PD-89-0663

Pivonia, S., \& Yang, X. B. (2004). Assessment of the potential year-round establishment of the soybean rust in the United States. Plant Disease, 89, 678-682. http://dx.doi.org/10.1094/PD-89-0678

Pivonia, S., Yang, X. B., \& Pan, Z. (2005). Assessment of epidemic potential of soybean rust in the United States. Plant disease, 89, 70-81. http://dx.doi.org/10.1094/PD-89-0678

Shokalu, O., Idowu, A. A., \& Misari, S. M. (2000). Prevalence of soybean rust in south western Nigeria. Tropical Oilseed Journal, 5, 70-80.

Yorinori, J. T., Paiva, W. M., Frederick, R. D., Costamilan, L. M., Bertagnilli, P. F., Hartmant, G. L., ... Nunes, Jr, J. (2005). Epidemics of soybean rust (Phkopsora pachyrhizi) in Brazil and Paraguay from 2001-2003. Plant Disease, 89, 675-677. http://dx.doi.org/10.1094/PD-89-0675 